\title{
Female tick Hyalomma marginatum marginatum SALIVARY GLANDS: PRELIMINARY STUDY ON PROTEIN CHANGES DURING FEEDING PROCESS AND ANTIGENS RECOGNIZED BY REPEATEDLY INFESTED CATTLE
}

\author{
TIKKI N.*, RHALEM A.*, SADAK A.** \& SAHIBI H.*
}

\section{Summary :}

Proteins extracted from salivary glands of unfed, three days and five days fed adult Hyalomma marginatum marginatum were analyzed by sodium dodecyl sulfate polyacrylamide gel electrophoresis (SDS-PAGE). We have noticed changes during the three feeding steps. Some proteins disappeared during feeding process $(23,38,39,40$ to 50,95 and $112 \mathrm{kDa})$, they might be proteins which were converted in other substances and are secreted. Other antigens 113 to 14,20,25, 29, 165 and $210 \mathrm{kDa}$ ) were synthesized as a result of tick attachment and feeding. They may be related to growth and development or are the ciment which fixed the adult. Also, three Holstein calves were infested five times with 100 pairs of adult ticks of the same species. The five infestations were performed two weeks from the previous infestation. The sera before infestations and after each infestation were used in western-blot analyses to identify antigens from five days salivary gland extracts of the primary infestation of ticks. Three antigens $(18.7,50$ and $80 \mathrm{kDa}$ ) were revealed weakly after the first and the second infestations by sera samples but not at infestation onward. Others $113.5,17$ to $18.5,25,30$, $70,133,176$ and $193 \mathrm{kDa}$ ) were revealed only by sera taken after manifestation of resistance (third infestation). A $13.5 \mathrm{kDa}$ antigen was particularly revealed when resistance had appeared and became more evident after the fourth and fitth infestations. The late antigens recognized might be associated with establishment of calves resistance against ticks.

KEY WORDS : Hyalomma marginatum marginatum, tick, salivary glands, antigens, SDS-PAGE, resistance.

MOTS CLÉS : Hyalomma marginatum marginatum, tiques, glandes salivaires, antigènes, gel SDS.PAGE, résistance.
Résumé : Glandes salivaires de la tique femelle Hyalomma MARGINATUM MARGINATUM : ÉTUDE PRÉEIMINAIRE SUR LES MODIFICATIONS PROTÉIQUES LIÉES À L'ENGORGEMENT ET LES ANTIGĖNES RECONNUS PAR LES BOVINS RÉGULIÈREMENT INFESTÉS

Des extraits de glandes salivaires de tiques adultes Hyalomma marginatum marginatum ont été analysés par SDS-PAGE. Trois stades de tiques ont été utilisés, des tiques à jeun ou des tiques après trois ou cinq jours de gorgement. Certains antigènes 123 , 38, 39, 40 à 50, 95 et 112 kDal disparaissent tôt durant le processus de gorgement. Ces antigènes sont probablement convertis et sécrétés en d'autres substances. D'autres antigènes 173 à $14,20,25,29,165$ et $210 \mathrm{kDa}$ l sont synthétisés après fixation de la tique et le début du gorgement. Ces antigènes doivent êtres liés à la croissance et au développement de la tique ou aux mécanismes de fixations de cette dernière. En outre, trois bovins de race Holstein ont fait l'objet de cinq infestations massives (100 paires de tiques par infestation) à intervalles de 15 jours et cela après gorgement de la dernière tique de l'infestation précédente. L'extrait des glandes salivaires des tiques de la première infestation après cina jours de gorgement a été analysé par la technique de western-blot en utilisant les sérums des bovins expérimentaux avant et après chaque infestation. Les bovins produisent des anticorps dès la première infestation. Trois antigènes $(18,7,50$ et $80 \mathrm{kDa})$ ont été révélés dès la première et la deuxième infestations, après ils ne sont plus détectés. D'autres antigènes $(13,5$, de 17 à 18,7, 133 et $193 \mathrm{kDa}$ ) n'ont été détectés qu'après la manifestation de la résistance /troisième infestation). L'antigène 13,5 kDa est particulièrement révélé dès l'apparition de la résistance et devient plus marqué à la quatrième et cinquième infestations. Les antigènes $(25,30,70,176 \mathrm{kDa})$ n'ont été détectés qu'après la quatrième et cinquième infestations. Ces antigènes tardivement reconnus pourraient être associés à l'établissement de la résistance des bovins vis-à-vis des tiques.
A vast amount of work remains to be done in the ongoing battle against ticks and tick-borne diseases. The vectors and pathogens can be most effectively studied by interactive, multidisciplinary research teams. The development of acaricide resistance (Nolan, 1990) calls for alternative control strategies for ticks and tick-borne diseases. The most promising of these alternatives, anti-tick vaccines, have

\footnotetext{
* Département de Parasitologie et Maladies Parasitaires, Institut Agronomique et Vétérinaire Hassan II, BP 6202, Rabat, Morocco. ** Département de Biologie animale, Université Mohamed V, Faculté des sciences, Rabat, Morocco.

Correspondence: Pr Hamid Sahibi. Fax: 212 7680424/7778135.
}

advanced from a possibility to a reality in the past ten years (Wikel, 1996). Several studies tried to give a clear picture of the immunology of acquired resistance (Brossard et al., 1991; De Castro \& Newson, 1993; Sahibi et al., 1997a,b,c). Information regarding immunogens responsible for specific responses is estimated. Indeed, it is already known that tick salivary glands perform numerous vital functions. They secrete cement which anchors mouth parts to the skin of the host (Kemp et al.,1982), and serve as primary osmoregulatory organs by which ions and water are eliminated in the host during feeding process (Kaufman \& Sauer, 1982). The salivary components maintain an intimate association between the parasite and the host (Kaufman, 
1989; Ribeiro, 1989; Gordon \& Allen, 1991; Ribeiro et al., 1992; Sauer et al., 1995). The pharmacological proprieties of saliva have more than one biologic activity. Salivary gland derived molecules have anti-hemostatic, vasodilatory, anti-inflammatory and immunosuppressive proprieties (Wikel et al., 1994; Wikel, 1996). Tick salivary glands contain apyrase which inhibits platelets aggregation by hydrolyzing adenosine triphosphate (ATP) and adenosine diphosphate (ADP) to adenosine monophosphate (AMP) and orthophosphate (Ribeiro, 1987; Titus \& Ribeiro,1985). Prostaglandin $\mathrm{E}_{2}$ $\left(\mathrm{PGE}_{2}\right)$, which is produced by tick salivary glands, inhibits platelet aggregation and causes vasodilatation (Champagne, 1994; Ribeiro et al., 1985). Salivary apyrase may prevent aggregation of neutrophils and mast cell degranulation (Ribeiro et al.,1990). Salivary gland extracts of Rbipicephalus appendiculatus contain a $65 \mathrm{kDa}$ anti-coagulant that inhibits the activity of factor $\mathrm{X}_{\mathrm{a}}$ or other components of the prothrombinase complex (Limo et al., 1991). Ixodes dammini saliva contains a kininase able to destroy bradykinin ( Ribeiro et al., 1988). Salivary glands are the focus of all medical and veterinary studies associated with ticks. It is widely believed that many diseases are caused by organisms inoculated into host body via tick saliva (Sauer, 1977; Ribeiro et al., 1987; Champagne, 1994). Therefore, salivary glands have been a subject of intensive studies, by semi-thin sectioning coupled with histochemistry (Binnington, 1978; Gill \& Walker, 1984) and electron microscopy (Krolak et al., 1982; Walker et al., 1985). These studies showed that the structure of ixodidae salivary glands is more complex than it was originally thought. Also, acinus types showed morphologic changes during attachment and feeding, and appeared to synthesize and secrete their products throughout the feeding period (Binnington, 1978; Gill \& Walker, 1987; Kaufman, 1989).

In a previous paper (Sahibi et al.,1998), it was reported that three calves infested five times with adults Hyalomma marginatum marginatum ticks exhibited manifestation of suppression of humoral responses to homologous salivary gland antigens followed by manifestation of immuno-resistance. The calves produced high titer of antibodies against antigen of tick salivary glands five days after the first infestation, but the titers declined thereafter. We observed that feeding and fertility of the ticks were severely inhibited by the fourth infestation, showing evidence of a resistance of calves. However, lower antibody titers were observed. On these observations, we investigate a preliminary study of salivary gland antigens to which calves reacted after each of the five heavy infestations and their relation with the manifestations of a resistance. The protein changes during tick feeding course were also investigated in this paper.

\section{MATERIALS AND METHODS}

TICKS

A colony of $H$. marginatum marginatum (Koch, 1844) ticks was maintained at the Institut Agronomique et Vétérinaire Hassan II, Rabat, Morocco, at $85 \pm 1$ relative humidity and $28^{\circ} \mathrm{C}$. Larvae and nymphs were confined to ears of rabbits using cloth-bags. Adult ticks used for salivary gland antigen preparation were fed on sheep using the same method. In all experiments, four- to five-week old adult ticks were used to infest cattle.

\section{Hosts}

Three Holstein (males), eight to twelve months old weighing $70-80 \mathrm{~kg}$, were used. The animals were provided from application farm where animals were wellkept. They had a regular treatment against ticks, so spontaneous infestation is not possible. During the experiment, they were kept on a small plot with bare dry ground which prevented spontaneous new tick infestation. The calves were fed artificially with cattle pellets and fresh alfalfa, and provided fresh water ad libitum.

\section{EXPERIMENT}

Our experiment consisted of infesting calves five times with 100 pairs (100 males and 100 females) of Hyalomma marginatum marginatum (Koch, 1844). Ticks were deposited in a cloth sack and confined to both ears of calves. Sacks were examined daily and the number of engorged ticks was recorded until all ticks which engorged had detached. Each female was weighed and incubated in individual container (8/2.5) until the end of the oviposition period, or discarded after 30 days if it failed to oviposit. The weight of the egg mass was also recorded. The five infestations were done at two-week intervals, after the last tick from the previous infestation had detached. The results of these part were published by Sahibi et al. (1998). In this report we studied the antigens recognized by antibodies in serum samples taken before and after each infestation. We also studied the salivary gland antigens of fed and unfed ticks.

\section{PREPARATION OF ANTIGENS}

Antigens were extracted from unfed, three and five days fed females of $H$. marginatum marginatum (Koch, 1844) reared under laboratory conditions. The ticks were washed in several solutions of $70 \%$ alcohol and in Phosphate Buffer Saline (PBS). The female ticks were fixed in wax and their salivary glands removed and placed in PBS (10 salivary glands/50 $\mu \mathrm{l}$ ). 
The samples were sonicated (10 times) at full power, 30 seconds each time, in ice. Homogenates were then centrifuged at $10,000 \mathrm{~g}$ at $4^{\circ} \mathrm{C}$ for $15 \mathrm{~min}$, and supernatants stored at $-20^{\circ} \mathrm{C}$. The protein content was determined using Lowry et al. (1951) method.

\section{ELECTROPHORESIS}

Electrophoresis of salivary gland extracts was performed essentially as described by Laemmli (1970). Salivary gland extracts were boiled for $5 \mathrm{~min}$ in sample loading buffer Tris-Hcl 0.5 M PH 6.8 with SDS and mercaptoethanol. Ten $\mu$ g of tick proteins were loaded per gel lane. Extracts were run on $5 \%$ to $20 \%$ acrylamide gradient gel prepared in Tris-Hcl buffer at $1.5 \mathrm{M}$, $\mathrm{pH}$ 8.8. Polypeptides were stained by silver staining.

\section{WESTERN BLOT}

Electrophoretic transfer and immunodetection of tick antigens was performed essentially as described by Tsang et al. (1983), using Tris-Buffer Saline [pH 7.5] (TBS), $2 \%$ Tween in TBS as a blocking buffer and Biorad horseradish peroxidase (HRPO) color developer containing 4-chloro 1-naphtol. Extracts from salivary glands were run on 5 to $20 \%$ gradient polyacrylamide gel. Separated proteins were transferred to nitrocellulose membrane, for one hour at $100 \mathrm{~V}$ in electrode solution (Tris $25 \mathrm{mM}$, glycine $112 \mathrm{mM}$ at SDS $0.1 \%$, $\mathrm{pH}$ 8.3). After transfer, nitrocellulose strips were incubated at room temperature for one hour in TBS-Tween $2 \%$. Membranes were incubated individually in bovine sera diluted at $1 / 100$ in TBS-Tween $0.2 \%$, for two hours at $37^{\circ} \mathrm{C}$. After washing, strips were incubated one hour at $37^{\circ} \mathrm{C}$ with Rabbit anti-bovine IgG (heavy and light chains specific) conjugated to HRPO $(1 / 2000)$. After three further washings with TBS-Tween $0.05 \%$, strips were colored with 4-chloro-1-naphtol and $\mathrm{H}_{2} \mathrm{O}_{2}$. The strips were rinsed in distilled water when purple bands appeared.

\section{RESULTS}

S alivary gland proteins were analyzed by SDSPAGE (Fig. 1) at three feeding steps. Silver staining of proteins allowed us to detect differences in the number and concentration of proteins revealed. In unfed ticks, 34 proteins were detected. After three days of feeding, we observed 37 proteins. Finally after five days of feeding 40 proteins were seen. Table I represents the relevant proteins. Most of these proteins were classified into eight groups.

Group 1: these proteins were revealed during the three steps of feeding $(34,42,50,72,80,165,193,200,220$ and $229 \mathrm{kDa}$ ).

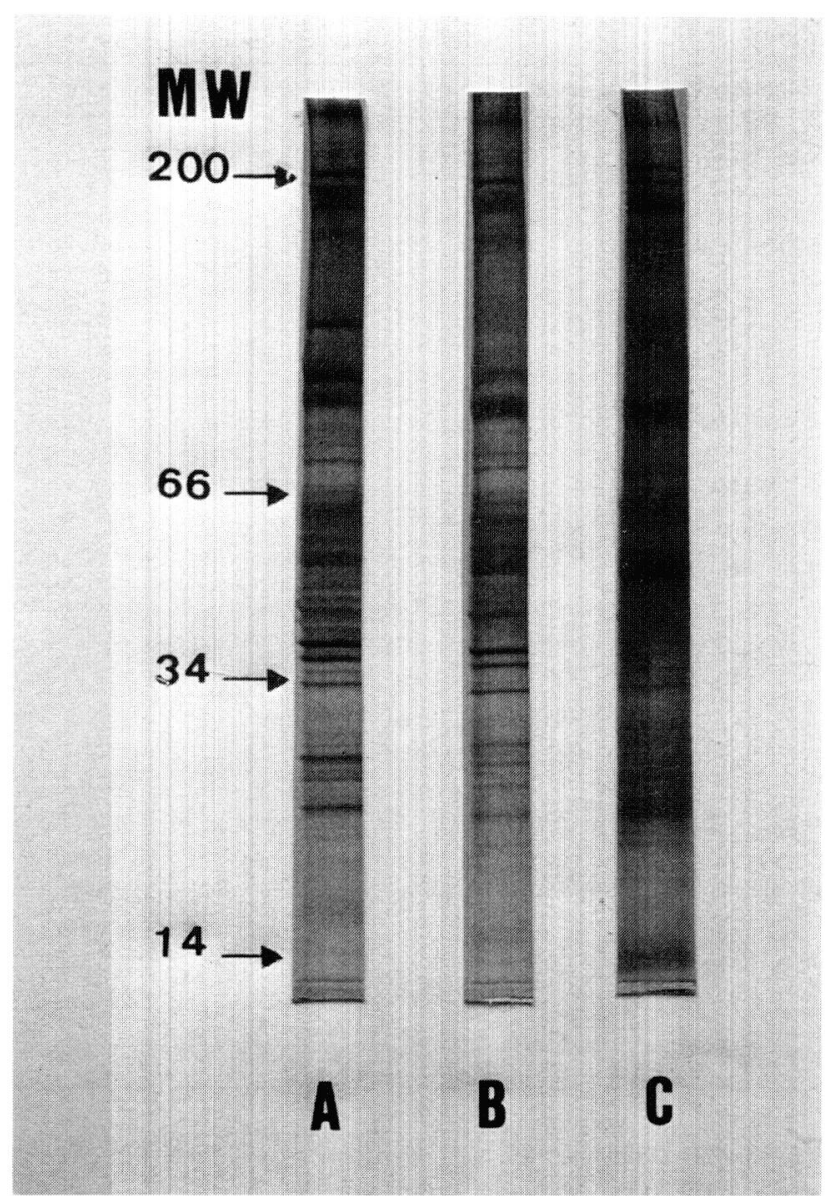

Fig. 1. - SDS-polyacrylamide gel electrophoresis pattern showing protein changes in salivary glands during feeding of Hyalomma marginatum female ticks.

A: Unfed ticks;

B: 3-days fed ticks;

C: 5-days fed ticks.

(Adjacent numbers represent relative molecular weight).

Group 2: (23, 26, 38 and $39 \mathrm{kDa})$ these proteins were present in salivary glands of unfed ticks and were seen to diminish as the tick feeding process progressed.

Group 3: $(95 \mathrm{kDa})$ this protein was present in unfed and three days fed ticks and disappeared in five days fed ticks.

Group 4: (40, 46, 48 and $112 \mathrm{kDa}$ ) these proteins were present only in unfed ticks.

Group $5:(20,25$ and $210 \mathrm{kDa})$ these proteins were present shortly in unfed ticks and became more strong thereafter.

Group $6:(176 \mathrm{kDa})$ this protein was present in unfed ticks, decreased during early stages of feeding and increased during subsequent stages.

Group 7: ( $29 \mathrm{kDa}$ ) this protein was obvious for a brief period in unfed ticks and increased after 72 hours of feeding to disappear at five days of feeding. 


\begin{tabular}{|c|c|c|c|}
\hline \multirow[b]{2}{*}{ Proteins } & \multicolumn{3}{|c|}{ Salivary gland present in ticks } \\
\hline & Unfed & 3 -days fed & 5-days fed \\
\hline 229 & ++ & ++ & ++ \\
\hline 220 & + & + & + \\
\hline 210 & - & $(+)$ & ++ \\
\hline 200 & ++ & ++ & ++ \\
\hline 193 & ++ & ++ & ++ \\
\hline 176 & - & $(+)$ & ++ \\
\hline 165 & + & + & + \\
\hline 112 & ++ & $(+)$ & - \\
\hline 95 & +++ & + & - \\
\hline 80 & ++ & ++ & + \\
\hline 72 & ++ & ++ & ++ \\
\hline 72 & ++ & ++ & + \\
\hline 50 & ++ & ++ & ++ \\
\hline 48 & + & - & - \\
\hline 46 & + & - & - \\
\hline 42 & ++ & ++ & + \\
\hline 40 & + & - & - \\
\hline 39 & +++ & ++ & $(+)$ \\
\hline 38 & +++ & + & $(+)$ \\
\hline 34 & ++ & ++ & + \\
\hline 29 & $(+)$ & + & - \\
\hline 26 & ++ & $(+)$ & $(+)$ \\
\hline 25 & $(+)$ & + & ++ \\
\hline 23 & ++ & + & + \\
\hline 20 & $(+)$ & $(+)$ & + \\
\hline 18.7 & - & - & + \\
\hline 17 & - & - & $(+)$ \\
\hline $13-14$ & - & - & +++ \\
\hline
\end{tabular}

- : protein not visible.

$(+)$ : lightly visible.

,,++++++ : relative amounts of protein visible.

Table I. - Major protein changes in salivary glands of Hyalomma marginatum marginatum females during three phases of feeding.

Group 8: (17, 18.7, around 13 and 14 and $133 \mathrm{kDa}$ ) these proteins became obvious only after five days of feeding.

A pool of sera of three calves at each infestation were used to characterize antigens from salivary gland extracts of five days fed ticks. Table II represents the relevant proteins revealed by sera of calves before and after each infestation with Hyalomma marginatum marginatum. We observed that no proteins were recognized by sera before infestations. Early after the first infestation the calves produced antibodies against tick antigens, and were present at subsequent infestations $(17 \mathrm{kDa})$. This protein became stronger since the third infestation. Some antigens were revealed after the first and the second infestations (18.7, 50 and $80 \mathrm{kDa}$ ) but very weakly or not at all by sera of the third infestation onward. After the third infestation, other antigens were revealed by the sera samples (13.5, from 17 to $18.7,133$ and $193 \mathrm{kDa}$ ). Interestingly, at the fourth and fifth infestations, the $13.5 \mathrm{kDa}$ antigen was more evident. Other proteins were recognized by sera of calves $(25,30,70,113$ and $176 \mathrm{kDa})$.

\begin{tabular}{cccccc}
\hline & \multicolumn{5}{c}{ Infestations } \\
\cline { 2 - 6 } Proteins & 1 th & 2 nd & 3 th & 4 th & 5 th \\
\hline 193 & - & - & +++ & - & - \\
176 & & - & - & - & +++ \\
133 & - & - & ++ & - & - \\
113 & - & - & - & - & ++ \\
80 & - & + & ++ & - & - \\
70 & - & - & - & +++ & +++ \\
50 & - & + & ++ & - & - \\
30 & - & - & - & - & ++ \\
25 & - & - & - & - & ++ \\
18.7 & - & + & ++ & - & - \\
17 & + & ++ & ++ & +++ & +++ \\
13.5 & - & - & ++ & +++ & +++ \\
\hline
\end{tabular}

$-:$ proteins not recognized.

,,++++++ : relative amounts of protein recognized.

Table II. - Salivary gland proteins detected by calve sera after each infestation.

\section{DISCUSSION}

T epeated feeding by ixodid ticks on a host may R produce a resistance to further tick feeding. - Acquired host resistance to tick feeding can result in reduced blood-meal volume, decreased engorgement weight, prolonged duration of feeding, diminished production of ova, reduced viability of ova, inhibited molting, and death of engorged ticks (Wikel, 1996). Many studies have shown resistance of hosts to various species of ticks (Wikel et al., 1994; Rechav \& Filden, 1995; Moran et al., 1996). Advances in studies of tick salivary glands showing their importance during ticks feeding provide a better understanding of the interrelated elements in acquisition and expression of host immunity to ticks. For the last decades many authors have tried to identify materials that could be used for vaccination against ticks. Shapiro et al., 1987, showed that a $90 \mathrm{kDa}$ molecule derived from Rhipicephalus appendiculatus salivary glands was implicated in induction of acquired resistance by rabbits. A $20 \mathrm{kDa}$ salivary gland polypeptide induces resistance to Amblyomma americanum (Brown \& Askenase, 1986). Our results show that attachment and short feeding were the primary stimuli for the synthesis of new salivary gland proteins. Major protein changes were observed, in the proteins of groups 2, 3, 4 which are present in the glands of unfed ticks and were absent or diminished in glands during later stages of feeding. These proteins might be secreted in the initial phase of feeding process or converted into other substances during the feeding process (Fawcett et al., 1981). Proteins of groups 5, 6, 7 and 8 appear to be synthesized as a result of tick attachment and feeding. These proteins may be related to growth and development of acinus types of salivary glands (Binnington, 1978; Kaufman, 1989). Comparable 
observations were made with Amblyomma americanum (Mc Swain et al., 1982; Jaworski et al., 1990) and Rbipicephalus appendiculatus (Shapiro et al., 1986).

These changes may have physiological significance from engorgement of the ticks. Advances in studies of tick salivary gland physiology allow new insights into biological properties of tick salivas (Kaufman, 1989; Sauer et al., 1995), and may help to understand a mechanism that make possible persistence of ticks in the field.

The study of salivary gland protein changes occurring during attachment and feeding may be a key for identification of vaccine candidates for efficient immune stimulation of the host. However, several investigations related to tick infestations (Moran et al., 1996; Sahibi et al., 1997a), and immunization (Wikel, 1996; Sahibi et al., 1997b,c) with tick extracts have highlighted the existence of host resistance. In attempt to identify antigens related to resistance, we have analyzed sera from calves after several infestations. The antigen used for the western blot was prepared from salivary glands of five days fed ticks. We have used this stage of feeding because the ultrastructure and functional development were completed (Binnigton, 1978; Gill \& walker, 1987; Kaufman, 1989). We noticed that during heavy repeated infestations a variety of antibodies are produced (Sahibi et al., 1998). Some antigens (18.7, 50, $80 \mathrm{kDa}$ ) were revealed with sera from first and second infestations and not by sera samples obtained after the third infestation. Other antigens, 13.5, 17 to 18.7, 133 and $193 \mathrm{kDa}$, were revealed for the first time only by sera taken when manifestation of anti-ticks resistance (third infestation) had appeared. This resistance was manifested by an inhibition of tick feeding and fertility. The percentage of engorged females significantly affected dropped to $55 \%$. Female weight was also affected by $68 \%$. Likewise, egg mass weight dropped to $66 \%$ (Sahibi et al., 1998). Because of consistent association between the time of revelation of these antigens and the manifestation of a resistance, we believe that they may be responsible for anti-tick protection. We also observed that a $13.5 \mathrm{kDa}$ protein may be particularly relevant for protection because it was revealed by calves sera after the third infestation and became more evident at fourth and fifth infestation. This antigen was only observed in salivary gland extracts when ticks had five days fed, so it is synthesized as a result of tick attachment. Perhaps it may be a factor which appears to have biologic activity which facilitates ticks engorgement. However, at the last infestations (fourth and fifth) other antigens were revealed $(25,30,70$ and $176 \mathrm{kDa})$. These lately recognized antigens might be associated with calves resistance against ticks. These possibly protection-associated antigens were observed in salivary gland extracts after three or five days feeding. However, it will be more interesting to identify an antigen in unfed sali- vary glands which induce early antibody production, and may be able to inhibit tick attachment and might be a good vaccine candidate. However, we have identified a $50 \mathrm{kDa}$ antigen present in unfed salivary glands. This antigen was revealed weakly by the first infestation sera and became very prominent after the second infestation. Association of this protein $(50 \mathrm{kDa})$ and antigens revealed after expression of a resistance of calves (thirth infestation) (13.5, 25 and $30 \mathrm{kDa}$ ), and immunization with this complex of molecules might be efficient for establishment of protection against Hyalomma marginatum marginatum.

Nevertheless, the previous studies on antigens associated with protection were essentially proteins with low molecular weight of 20 or $25 \mathrm{kDa}$ as reported by Brown (1988) or $29 \mathrm{kDa}$ as reported by Barriga et al. (1992) induce a resistance against Amblyomma americanum. Rutti \& Brossard (1992) reported vaccination against Rhipicephalus appendiculatus with a $20 \mathrm{kDa}$ molecule which induced a protection in different host species against different ticks. In our results, we also observed that antigens with low molecular weight (13.5, 25 and $30 \mathrm{kDa}$ ) seem to be related to protection. The $13.5 \mathrm{kDa}$ protein may be particularly relevant to protection because it was revealed with the same strength by the sera of the third to fifth infestations when calves were resistant to tick infestations (Sahibi et al., 1998). Indeed, the role of this molecule in acquisition and expression of anti-tick protection should be further evaluated. The antigen $25 \mathrm{kDa}$ where present in the three feeding steps, this protein can also confer a protection against Hyalomma marginatum marginatum and act when tick was just attached to host. Our results demonstrated that production of several antigenic polypeptides was induced by the feeding process. Immuno-reactive polypeptides from the salivary glands of Hyalomma marginatum marginatum females have been identified. Certain polypeptides are apparently induced by attachment and feeding. Some hypothesis were made on importance of these antigens, however more proof must be given. Besides, antigens of similar molecular weight were found in other tick species suggesting that these proteins are conserved. Antigens identified through these studies may prove useful in efforts to artificially induce immunity to tick feeding. So more investigation must be done to characterize these antigens and perhaps find a cross reactivity with other Hyalomma species.

\section{REFERENCES}

Barriga O.O., Andujar F., SAhibi H. \& Andrzejewski W.J. Antigens of Amblyomma americanum ticks recognized by repeatedly infested sheep. Journal of Parasitology, 1991, 77, $710-716$. 
BinNington K.C. Sequential changes in salivary gland structure during attachment and feeding of the cattle tick, Boophilus microplus. International Journal for Parasitology, 1978, 8, 97-115.

Brossard M., RutTI B. \& Haug T. Immunological relationships between host and ixodid ticks. In: Parasite-bost associations: coexistence or conflict, ed. Toft C.A., Aeschliman A., Bolic L., 1991, pp.177-200. Oxford: Oxford Univ. Press.

BRown S.J. \& ASKenASE P.W. Amblyomma americanum: physiochemical isolation of a protein derived from the tick salivary gland that is capable of inducing immune resistance in guinea pigs. Experimental Parasitology, 1986, 62, 40-50.

BRown S.J. Western blot analysis of Amblyomma americanum-derived stage-specific and shared antigens using serum from guinea pigs expressing resistance. Veterinary Parasitology, 1988, 28, 163-171.

De Castro J.J. \& Newson R.M. Host resistance in cattle tick control. Parasitology Today, 1993, 9, 13-17.

Champagne D.E. The role of salivary vasodilators in blood feeding and parasite transmission. Parasitology Today, 1994, 10, 430-433.

Dharampaul S., Kaufman W.R. \& Belosevic M. Differential recognition of saliva antigens from the ixodid tick Amblyomma bebraeum (Acari: Ixodidae) by sera from infested and immunized rabbits. Journal of Medical Entomology, 1993, 30, 262-266.

FAwCett D.W., Doxey S.J. \& Buscher G. Salivary gland of the tick vector (Rhipicephalus appendiculatus) of east coast fever. I. Ultrastructure of the type III acinus. Tissue $\&$ Cell, 1981, 13, 209-230.

GILl H.S. \& WALKeR A.R. Preliminary histochimical studies on the salivary glands of unfed and feeding Hyalomma anatolicum. In: Acarology VII (Edited by Griffiths D.A. \& Bowman C.E.) 1984 , 365. Ellis Harwood, Chichester.

GILl H.S. \& WALKER A.R. The salivary glands of Hyalomma anatolicum anatolicum: structural changes during attachment and feeding. International Journal for Parasitology, 1987, 17, 1381-1392.

GORDON J.R. \& AlLEN J.R. Factor V and VII anticoagulant activities in the salivary glands of feeding Dermacentor andersoni ticks. Journal of Parasitology, 1991, 77, 167-170.

Jaworski D.C., Muller M.T., Simmen F.A. \& NeEdham G.R. Amblyomma americanum: identification of tick salivary gland antigens from unfed and early feeding females with comparisons to Ixodes dammini and Dermacentor variabilis. Experimental Parasitology, 1990, 70, 217-226.

KAUfMAN W.R. \& SAUER J.R. Ion and water balance in feeding ticks: mechanisms of tick excretion. In: Tick physiology (edited by Obenchain F.D. \& Galun R.) Perg. Press, Oxford, 1982.

KaUfMAN W.R. Tick-host interaction: a synthesis of current concepts. Parasitology Today, 1989, 5, 47-56.

Kemp D.H., Stone B.F. \& Binnington K.C. Tick attachment and feeding: role of the mouthparts, feeding apparatus, salivary gland secretions and the host response. In: $P b y$ siology of Ticks, Obenchain \& Galun R. (eds.). Pergamon Press, Oxford, U.K., 1982, 119-168.
Krolak J.M. ,Ownby C.L. \& Sauer J.R. Alveolar structure of salivary glands of the lone star tick Amblyomma americanum unfed females. Journal of Parasitology, 1982, 68, 61-82.

LAEMMLI U.K. Cleavage of structural proteins during the assembly of the head of bacteriophage T4. Nature (London), 1970, 227, 680-685.

Limo M.K., Voigt W.P., Tumbo-Oeri A.G. \& Ole-Moi Yoi OK. Purification and characterization of an anticoagulant from the salivary glands of the ixodid tick Rbipicephalus appendiculatus. Experimental Parasitology, 1991, 2, 418-429.

Lowry O. H., Rosebrough N.J., Farr A.L. \& Randall R.J. Protein measurement with the folin phenol reagent. Journal of Biological Chemistry, 1951, 193, 265-275.

Mc Swain J.L., Essenberg R.C. \& Sauer J.R. Protein changes in the salivary glands of the female lone star tick, Amblyomma americanum, during feeding. Journal of Parasitology, 1982, 68, 100-106.

Moran M.C., Niagrura G. \& Pegram R.G. An assessment of host resistance to ticks on cross-bred cattle in Burundi. Medical and Veterinary Entomology, 1996, 10, 12-18.

Nolan J. Acaracide resistance in single and strategies for control. Parassitologia, 1990, 32, 45-53.

ReChAV Y. \& Fielden L.J. The effect of host resistance on the metabolic rate of engorged females of Rhipicephalus evertsi evertsi . Medical and Veterinary Entomology, 1995, 9, 289292.

Ribeiro J.M.C, Makoul G.T, Levine J, Robinson D.R. \& SpielMAN A.O. Antithemostatic, anti-inflammatory and immunosuppressive properties of the saliva of a tick, Ixodes dammini. Journal of Experimental Medicine, 1985, 161, 332-344.

Ribeiro J.M.C., Mather T.N., Piesman J. \& Spielman A. Dissemination and salivary delivery of lyme disease spirochetes in vector ticks (Acari: Ixodidae). Journal of Medical Entomology, 1987, 24, 201-205.

Ribeiro J.M.C., Makoul G.T. \& Robinson D.R. Ixodes dammini: evidence for salivary prostacyclin secretion. Journal of Parasitology, 1988, 74, 1068-1069.

RiBEIRo J.M.C. The role of saliva in tick-host interactions. Experimental and Applied Acarology, 1989, 7, 269-278.

Ribeiro J.M.C., Evans P.M., MCSWAIN J.L. \& SAUER J. Amblyomma americanum: characterization of salivary prostaglandins $\mathrm{E}_{2}$ and $\mathrm{F}_{2 \mathrm{a}}$ by RP-HPLC/bioassay and gas chromatographymass spectrometry. Experimental Parasitology, 1992, 74, 112-116.

RutTI B. \& BRossard M. Repetitive detection by immunoblotting of an integumental $25 \mathrm{kDa}$ antigen in Ixodes ricinus and a corresponding $20 \mathrm{kDa}$ antigen in Rhipicephalus appendiculatus with sera from pluriinfested mice and rabbits. Parasitology Research, 1989, 75, 325-329.

RutTI B. \& BROSSARD M. Vaccination of cattle against Rhipicephalus appendiculatus with detergent solubilized tick tissue proteins and purified $20 \mathrm{kDa}$ protein. Annales de Parasitologie Humaine et Comparée, 1992, 67, 50-54.

Sahibi H., Rhalem A. \& Barriga O.O. Cumulative effect of sequential host's immunity on, and common antigens in nymphs and adults of Hyalomma marginatum marginatum Koch (Ixodidae). Acarology IX: proceedings section 8, Mites E Allergies, 1997a, 6, 511-512. 
Sahibi H., Rhalem A. \& Barriga O.O. Field and artificially induced resistance of cattle to Hyalomma marginatum Koch (Ixodidae). Acarology IX: proceedings section 8, Mites \& Allergies, 1997b, 8, 519-521.

SAHibi H., Rhalem A. \& Barriga O.O. Comparative immunization power of infections salivary extracts, and intestinal extracts of Hyalomma marginatum marginatum in cattle. Veterinary Parasitology, 1997c, 68, 359-336.

SaHibi H., Rhalem A. \& Tikki N. Comparison of effects of low and high infestations on acquired cattle tick resistance: Hyalomma marginatum marginatum. Parasite, 1998, 5, 69-74.

SAUER J.R. Acarine salivary glands-physiological relationships. Journal of Medical Entomology, 1977, 14, 1-9.

Sauer J.R., McSwain J.L., Bowman A.S. \& Essenberg R.C. Tick salivary gland physiology. Annual Revue of Entomology, 1995, 40, 245-267.

SHAPIRO S.Z., VOIGT W.P. \& FUJISAKI K. Tick antigens recognized by serum from a Guinea pig resistant to infestation with the tick Rbipicephalus appendiculatus. Journal of Parasitology, 1986, 72, 454-463.

Shapiro S.Z., Buscher G. \& Dobbelaere DAE. Acquired resistance to Rhipicephalus appendiculatus (Acari: Ixodidae): identification of an antigen eliciting resistance in rabbits. Journal of Medical Entomology, 1987, 24, 147-154.

TItUs R.G. \& Ribeiro J.M.C. The role of vector saliva in transmission of arthropod-borne disease. Parasitology Today, 1990, 6, 157-160.

Tsang V.C.W., Peralta J. M. \& Simons A.R. Enzyme-linked immunoelectrò-transfer blot technic (EITB) for studying the specificities of antigens and antibodies. Separated by gel electrophoresis. Methods in Enzymology, 1983, 92, 377-391.

WALKER A.R., FleTCHER J.D. \& Gill H.S. Structural and histochemical changes in the salivary glands of Rhipicephalus appendiculatus. International Journal for Parasitology, 1985, 15, 81-100.

Wheeler C.M., Coleman J.L. \& Benach J.L. Salivary gland antigens of Ixodes dammini are glycoproteins that have interspecies cross-reactivity. Journal of Parasitology, 1991, 77, 965-973.

Wikel S.K., Ramachandra R.N. \& Bergman D.K. Tick-induced modulation of the host immune response. International Journal for Parasitology, 1994, 24, 59-66.

WIKEL S.K. Host immunity to ticks. Annual Revue of Entomology, 1996, 41, 1-22.

Willadsen P., Bird P., Cobon G.S. \& Himgerford J. Commercialization of recombinant vaccine against Boophilus microplus. Parasitology, 1995, 110, 43-50.

Reçu le 19 décembre 1998 Accepté le 14 octobre 1999 